\title{
Handelinge se uitbeelding van die rol van vroue in die vroeë kerk
}

\author{
Llewellyn Howes \\ Departement Nuwe-Testamentiese Wetenskap \\ Universiteit van Pretoria
}

\begin{abstract}
Acts and the role of women in the early church

The aim of this article is to determine what the role of women in the church of the first century was according to Acts. Amongst other things it pertains to the situation of women within the community of believers on a daily basis. It not only includes their contribution to faith services and the faith community as a whole, but also how the faith community perceived them. What part did they play and what positions of leadership did they hold? Did their gender exclude them from exercising certain leadership roles? What was the gender-specific view of Christians? Establishing the historicity of every pericope in Acts is not the main aim. However, the article subscribe to the historicity of the overall picture of the role women played in the early church.
\end{abstract}

\section{HUISKERKE}

Hierdie artikel poog om die rol of posisie van vroue in die vroeë kerk vas te stel deur van Handelinge gebruik te maak. Die eerste paragraaf ondersoek huiskerke en die invloed wat hierdie fenomeen op die rol van vroue in die vroeë kerk gehad het. Hierdie inligting word dan gebruik om perikope vanuit Handelinge wat oor vroue handel, wetenskaplik te lees. Uiteindelik word ander geleerde opinies op grond van die inhoud van hierdie artikel bevraagteken en 'n selfstandige posisie ingeneem.

Voor ons begin met die soektog na die rol van vroue in die vroeë kerk, moet daar eers 'n paar woorde oor die fenomeen van huiskerke gesê word. Die volgelinge van die Jesus-beweging het in die vroegste ontwikkelingsfase van die kerk in huise bymekaargekom (Beck 1990:294; Witherington III 1988:80). Huiskerke is die oudste Christelike organisasie-eenhede wat aan

\footnotetext{
* Hierdie artikel is 'n verwerking van 'n gedeelte van die MTh-skripsie van Llewellyn Howes, voorberei onder leiding van prof dr A G van Aarde, Fakulteit Teologie, Universiteit van Pretoria (2004).
} 
ons bekend is (Malone 2001:69). Die huiskerke het losieshuise vir rondtrekkende evangeliste geword, maar was ook gebruik as bymekaarkomplek vir die vroeë Christene waar hulle kon preek en die Skrif kon bestudeer (Beck 1990:295; Witherington III 1988:146). Lede van die beweging wat huise met genoeg ruimte vir die bymekaarkoms van 'n groep gelowiges gehad het, het hulle huise vir sulke byeenkomste beskikbaar gestel en opgetree as gashere vir diegene wat daarin saamgekom het (Tucker \& Liefeld 1987:57, 80). Die huiseienaars is as gevolg van hulle vrygewigheid gesien as weldoeners van diegene wat in hulle huise vergader (vgl Witherington III 1988:110; Tucker \& Liefeld 1987:57). Die eienaars van hierdie huise was gewoonlik redelike ryk gelowiges, aangesien die huise groot genoeg moes wees om die byeenkoms van 'n groep mense te akkomodeer (vgl Malone 2001:69; Witherington III 1988:110). Die oorgrote meerderheid van antieke mense was brandarm (Malina 1993:92; kyk Oakman 1996). Hierdie arm meerderheid sou net-net genoeg geld hê om hulleself te huisves. Die groot onderskeid in die antieke samelewing was tussen die elite wat een persent van die bevolking uitgemaak het, en die boerestand (peasantry) wat die grootste deel van die bevolking uitgemaak het (Crossan 1994:25). Die meeste eienaars en stigters van huiskerke was klaarblyklik handwerkers (vgl parr 2.7; 2.9) (Hand 16:14; 18:13). Alhoewel dit waar is dat handwerkers soms baie arm was en nie belangrik in die oë van die elite was nie, is daar sprake van handwerkers wat groot finansiële wins gemaak het. Selfs al het die sosiale waarde van sulke ryk hande-arbeiders nie altyd in die oë van die een persent elite gestyg nie, is hulle wel deur die arm massas gerespekteer. Wanneer sulke mense in die vorm van weldoenerskap aan die gepeupel hulp verleen, het hulle sosiale status in die oë van die armes nog meer gestyg. Dit is presies wat in die vroeë kerk gebeur het wanneer ryk handwerkers hulle huise aan die volgelinge van die Jesus-beweging beskikbaar gestel het (vgl parr 2.6; $2.7 ; 2.9$ ). Hulle sosiale status buite en veral binne die kerk, te same met hulle weldoenerskap het outomaties van hierdie huiseienaars gesagsfigure in die vroeë kerk gemaak (vgl Witherington III 1988:80, 106, 110; Tucker \& Liefeld 1987:57, 80). Daar moet egter 'n onderskeid tussen Joodse en Grieks-Romeinse sienings van hande-arbeid gemaak word. Die Joodse elite het in 'n groter mate as die Grieks-Romeinse elite neergekyk op mense wat met hulle hande werk (Witherington III 1998:546). Net sommige van die Grieks-Romeinse elite het nog in die eerste eeu op fisiese werk neergekyk (Witherington III 1998:546). Die meerderheid welvarende handwerkers het wel in die oë van die eersteeeuse Grieks-Romeinse elite in status toegeneem.

Hellenistiese vroue het grootskaalse vryheid ervaar, wat deur baie van hulle gebruik is om besighede te begin en hulle sosiale status te verbeter 
(Witherington III 1998:335-336). Sommige van hierdie vroue het belangrike sosiale, politiese en godsdienstige rolle in hulle gemeenskappe vervul. Hulle groot huise was ook 'n teken van hulle prominensie en weelderige leefwyse. Daar is geen voorbeelde waar Paulus ' $n$ huiskerk stig nie, maar hy bedank telkens diegene wat tydens sy sendingreise aan hom verblyf voorsien het (kyk Malone 2001:69; Reimer 1995:219). 'n Vrou word in meer as een geval as so 'n gasheer uitgesonder (D'Angelo 2002:67; Malone 2001:69; Reimer 1995:260; Beck 1990:294-295; Witherington III 1988:145; vgl Tucker \& Liefeld 1987:57; kyk Wire 1990:63, 183). Indien 'n vrou die eienaar van so 'n huis was, het dit haar reputasie en invloed binne die gemeente aansienlik vermeerder. Sy was gelykstaande aan 'n $\mu \eta ́ \tau \eta \rho ~ \sigma v \nu a \gamma \omega \gamma \hat{\eta} s$ (Witherington III 1988:145). Dit was onvermydelik dat sulke prominente vroue met huiskerke uiteindelik ook as die leiers in die onderskeie gemeentes sou funksioneer. Hierdie vroue was ryk weduwees, geskeide vroue, of vroue wie se eggenote ongelowig was (Barrett 1998:784). Die bestaan en voortbestaan van die vroeë kerk was afhanklik van die gasvryheid van sulke vooraanstaande vroue (Witherington III 1988:145). Die bestaan van huiskerke was egter nie net voordelig vir die vroulike huiseienaars nie, maar ook vir die res van die vroue (Beck 1990:295). Die huis was die private sfeer waarin die vrou 'n mate van invloed kon uitoefen en gesag kon afdwing, terwyl die openbare sfeer die domein van die mans was (Reimer 1995:218; Beck 1990:295; kyk Malina 1993:49-50). Die verskynsel dat 'n groep mense in 'n huis byeenkom, het tot gevolg gehad dat die skeidslyn tussen die private en publieke sfere, en daarom ook tussen die outoriteit van mans en die onderdanigheid van vroue vervaag het (vgl Reimer 1995:218, 267; Wire 1990:183). Hierdie verwarring het die geleentheid aan vroue gegee om gesagsfigure in die vroeë kerk te word, asook die ruimte geskep om 'n diskriminasievrye gemeenskap te begin (kyk Küng 2001:4-5; Reimer 1995:267; Wire 1990:183). Die diskriminasievrye ideologie van Jesus en die vroegste Jesus-beweging het op sy beurt weer die fondasie vir vroulike leierskap in die eerste huiskerke gelê (kyk Küng 2001:45, 7; Malone 2001:66; Crossan 1994:54-74; Beck 1990:295; Witherington III 1988:108). Wainwright (1991:335) beskryf hierdie proses as volg:

Since, however, many of the beliefs and attitudes of the Jesus movement and therefor of the early christian communities were egalitarian and in conflict with the social structure of Palestinian Jewish society at the beginning of the first century and of the Greco-Roman society generally, it seems that the household model generally adopted by the early christians was not that of the patriarchal familial household but that of the collegia ${ }^{1}$ or voluntary association ... The various types of voluntary associations which

\footnotetext{
${ }^{1}$ Skuinsdruk in oorspronklike
} 
existed at the time ... were generally characterized by more egalitarian structures which afforded greater opportunities for leadership and participation to all, especially women and slaves.

\section{VROUE IN HANDELINGE}

\subsection{Vroue en die ontstaan van die kerk}

$\mathrm{Na}$ Jesus se hemelvaart (ongeveer $30 \mathrm{nC}$ ) vergader sy volgelinge in Jerusalem. In Handelinge 1:14 beskryf Lukas die wese van hierdie samekoms: "Hulle het almal eensgesind volhard in die gebed saam met 'n aantal vroue, onder wie ook Maria die moeder van Jesus was. Sy broers was ook by" (NAB). Die eerste blik in Handelinge op die begin van 'n nuwe era, is die stelling dat vroue deel was van die vroegste na-Pase Jesusbeweging en aan die gebed deelgeneem het (Martin 1994:771; Tucker \& Liefeld 1987:63; Stagg \& Stagg 1978:227; vgl Beck 1990:288; Bruce 1976:74). Maria word moontlik om dieselfde rede as die broers van Jesus eksplisiet genoem, naamlik dat hulle nie voorheen in Jesus se Messiasskap geglo het nie (Tucker \& Liefeld 1987:63; vgl Haenchen 1971:155). Lukas lig haar moontlik uit (deur haar pertinent te noem) om haar substansiële bydrae in die ontstaansfase van die vroeë kerk te beklemtoon (Dunn 1996:16; Kistemaker 1990:60). Die "aantal vroue" bestaan waarskynlik uit diegene wat tydens Jesus se voorPase bediening reeds sy volgelinge was (vgl Luk 8:2-3; 23:49-56; 24:1-10) (Beck 1990:288; Kistemaker 1990:59; Haenchen 1971:155). In die heel eerste na-Pase byeenkoms mag beide mans en vroue aan die gebed deelneem (Tucker \& Liefeld 1987:63). Daar word geen onderskeid tussen die werk van mans en vroue afsonderlik gemaak nie (Beck 1990:288). In Handelinge 1:21 sonder Lukas egter manlikheid spesifiek uit as 'n kriterium vir apostelskap (D'Angelo 2002:50). Tog lei geleerdes op grond van die bogenoemde af dat vroue nie net 'n groot deel van die vroegste na-Pase geloofsgemeenskap uitgemaak het nie, maar ook saam met die mans in gebed vir die uitstorting van die Heilige Gees gewag het (Beck 1990:289).

In Jerusalem neem die volgelinge van Jesus deel aan die Pinkstergebeure en word hulle sodoende met die Heilige Gees vervul (Hand 2:1-4) (Malone 2001:67). In Handelinge 2:1-13 is daar geen suggestie dat mans alleen by die gebeure betrokke was nie. Daaruit kan ons aflei dat daar waarskynlik mans en vroue by die gebeure rondom die uitstorting van die Heilige Gees betrokke was. Die waarskynlike teenwoordigheid van vroue by die Pinkstergebeure word eerstens deur die boonste aanhaling (Hand 1:14) en tweedens deur die toespraak van Petrus direk daarna (Hand 2:14-36) bevestig (Kee 1997:49; vgl Tucker \& Liefeld 1987:64; Stagg \& Stagg 
1978:227). Hy haal Joël 2:28-32 aan, waarin daar geprofeteer word dat die

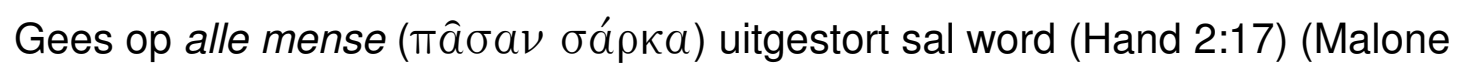
2001:67-68; Reimer 1995:251; Beck 1990:289; Stagg \& Stagg 1978:228). Die voorafgaande Pinkstergebeure word dus deur Lukas gesien as die vervulling van hierdie Ou-Testamentiese belofte (Barrett 1994:135; vgl Beck 1990:289).

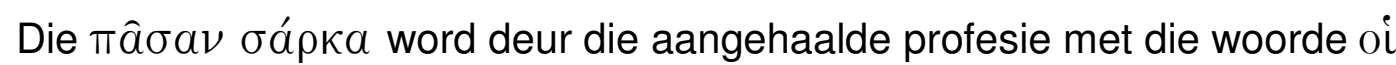

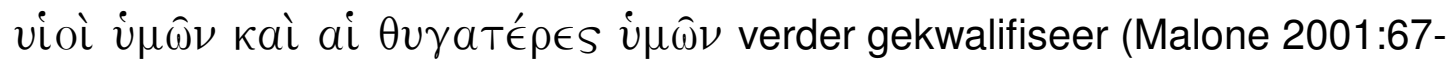
68; vgl Kistemaker 1990:89). Geslag is dus hier irrelevant (Barrett 1994:137). "Julle seuns en julle dogters" verwys hier na die nageslag van Israel gedurende die tydperk van die profesie. Dit verwys dus in die konteks van

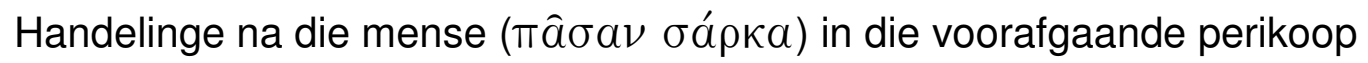
(Hand 2:1-13) (Reimer 1995:251). Daar word vermeld dat hierdie mense as profete sal optree (Hand 2:17). Lukas ag vroue en mans dus ewe geskik om as profete op te tree (Reimer 1995:251; Kistemaker 1990:89; Tucker \& Liefeld 1987:64; Jervell 1984:154). Dieselfde uitspraak word in vers 18 ten opsigte

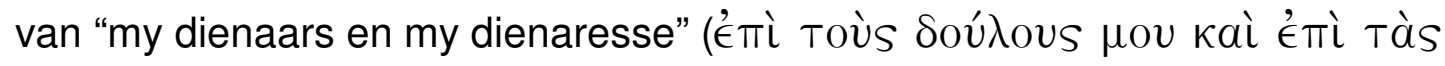

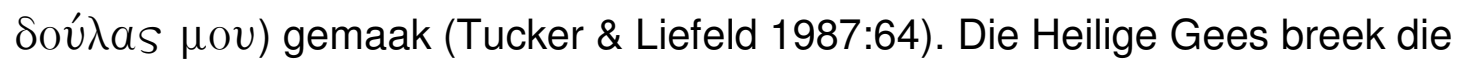
mure af wat deur geslag, ras en ouderdom opgebou is (Martin 1994:776; Beck 1990:289-290; Kistemaker 1990:89).

Uit dit alles kan ons nie net aflei dat vroue volgens Lukas by die gebeure van Pinkster betrokke was nie, maar ook dat hy vroue en mans waarskynlik gelyk ag en dat albei geslagte ewe veel reg het om te profeteer (Reimer 1995:251; Beck 1990:289; Tucker \& Liefeld 1987:64; kyk Küng 2001:4-5). Die Pinkstergebeure, 'n Ou-Testamentiese aanhaling en die toespraak van seker die belangrikste apostel in die vroeë kerk (Petrus) legitimeer Lukas se egalitêre ekklesiologie (Tucker \& Liefeld 1987:64; kyk Küng 2001:4-5). Hierdie gebeure en Lukaanse ideaal dien as die inleidende hermeneutiese sleutel waarmee die res van Handelinge oopgesluit word (Tucker \& Liefeld 1987:64). Die res van Handelinge toon aan hoedat die OuTestamentiese profesie in hierdie perikoop prakties in vervulling gaan (Tucker \& Liefeld 1987:64; vgl Barrett 1994:135).

Op grond van Handelinge 2:43-47 en 4:32-37 kan 'n mens tot dieselfde gevolgtrekking kom. In daardie perikope kry 'n mens die idee van 'n gemeenskap wat egalitêr funksioneer (Küng 2001:4-5). Alhoewel geslag nie hier ter sprake is nie, word die beeld geskets van 'n gemeenskap wat in alles mekaar se gelykes is (Küng 2001:4-5; Malone 2001:68). Hierdie perikoop onderskryf dus die tendens in die vroegste gemeentes om mans en vroue gelyk te ag. 


\section{2 "Mans en vroue"}

'n Tema wat regdeur Handelinge voorkom, is die bekering van beide mans en

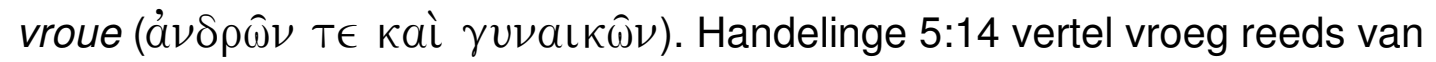

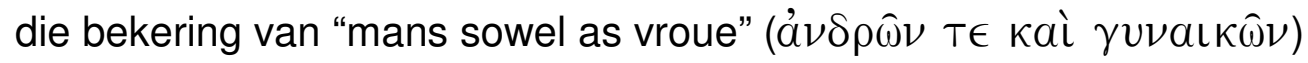
(Witherington III 1998:226; Arlandson 1997:146-147; Martin 1994:777-778; Kistemaker 1990:192; Witherington III 1988:144). Lukas sê op drie plekke in Handelinge pertinent dat Saulus "mans en vroue" ( $\tau \in$ ă $\nu \delta \rho a s$ kaì yuvaîkas) vervolg het (Hand 8:3; 9:2; 22:4) (Arlandson 1997:183; Beck 1990:294; Witherington III 1988:144; vgl Martin 1994:777). Lukas suggereer hier dat vroue in die Jesus-beweging so baie, invloedryk en/of belangrik was, dat Saulus nie die beweging sou kon stop sonder om beide mans en vroue te vervolg nie (Beck 1990:294; Witherington III 1988:144). In Handelinge 8:12 lees ons dat beide mans en vroue in Samaria gelowig geword het en gedoop is (Martin 1994:778; Tucker \& Liefeld 1987:66). Ons gaan later bespreek wat Lukas bedoel as hy in Handelinge 17:4 noem dat "' $n$ groot aantal godvresende Grieke en 'n aansienlike getal vooraanstaande vroue" gelowig geword het (par 2.8). In Handelinge 17:12 noem Lukas dat "mans sowel as vooraanstaande vroue" gelowig geword het (par 2.8). Die man-vrou parallellisme kom in 'n ander vorm in Handelinge 17:34 voor. Lukas noem twee persone wat in Atene tot bekering gekom het by die naam (Arlandson 1997:136). Hulle is Dionisius en Damaris (Arlandson 1997:136). Die manlike en vroulike eiename is verteenwoordigend van al die gelowiges wat in Atene gelowig geword het (Witherington III 1988:144). Die laasgenoemde feit word

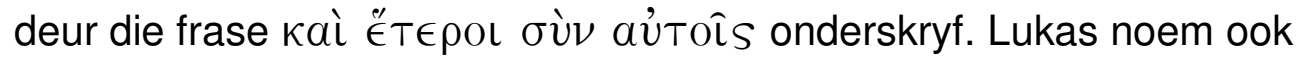
eksplisiet dat Damaris 'n vrou ( $\gamma \nu \nu \eta)$ was, waarskynlik om misverstand te voorkom. Met hierdie parentese onderstreep Lukas die belang van vroue in die vroeë kerk. Hy doen waarskynlik ook dieselfde in Handelinge 5:1-11 (par 2.3), Handelinge 9:32-42 (par 2.5), Handelinge 16:12-40 (par 2.7) en Handelinge 27:34 (Witherington III 1988:129, 143-144, 147-150; vgl Martin 1994:778-779). Die "mans en vroue"-tema impliseer moontlik ook dat Lukas geen diskriminerende onderskeid tussen manlike en vroulike gelowiges maak nie (D'Angelo 2002:67; Witherington III 1988:129). In Handelinge 21:5 word Paulus deur mans, vroue en kinders na sy handelskip vergesel (Arlandson 1997:147). Die feit dat die vroue vir Jesus in die publiek (d w s die man se domein) vaarwel wens, plaas hulle op gelyke sosiale vlak met die mans in daardie perikoop (Arlandson 1997:147). Die Lukaanse tendens om van "mans en vroue" te praat, ondersteun die gevolgtrekking van paragraaf 2.1 dat die vroegste gemeentes (en ook Lukas) 'n inklusiewe houding teenoor gesag gehad het (vgl Witherington III 1998:226; Kee 1997:77). Hierdie inklusiewe ingesteldheid het die moontlikheid van vroulike leierskap oopgemaak. 


\subsection{Ananias en Saffira}

Die eienaam van Ananias is waarskynlik 'n sinspeling op die Hebreeuse

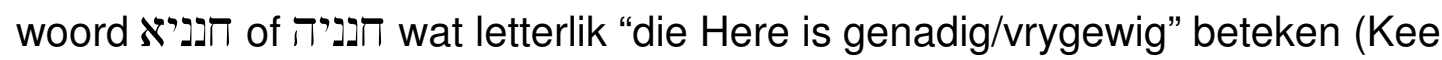
1997:75; Barrett 1994:264; Kistemaker 1990:181; Bruce 1976:132; Williams 1964:88). Die eienaam "Saffira" verteenwoordig die vroulike vorm van die Hebreeuse adjektief שפיר wat "mooi" of "pragtig" beteken² (Witherington III 1998; Kee 1997:75; Barrett 1994:264; Kistemaker 1990:182; Bruce 1976:132; Williams 1964:88; Robertson 1930:61). Albei was aktief by die gebeure betrokke (Martin 1994:779). ${ }^{3}$ Saffira was dus nie 'n slagoffer in die verhaal van Handelinge 5:1-11 nie (Martin 1994:779). Ananias en Saffira was ewe skuldig (Martin 1994:779; Witherington III 1988:143; vgl Bruce 1988:107). Die implisiete betrokkenheid van Saffira by die bedrog in vers 1 word in vers 2 eksplisiet gestel: "Met die medewete van sy vrou het hy van die eiendom se verkoopprys vir hulleself agtergehou en net ' $n$ gedeelte daarvan gebring en vir die apostels gegee" (NAB) (vgl Martin 1994:779). Die werkwoord $\sigma v \nu \in t \delta v i ́ \eta S$ veronderstel die genoemde huweliksooreenkoms en maak eksplisiet dat Saffira deel gehad het in die plan om die kerk te mislei (Barrett 1994:265; Marguerat 2002:174; kyk Robertson 1930:59). In vers 9 word beide se skuld in die bedrog deur die frase $\sigma v \nu € \phi \omega \nu \eta \dot{\theta} \theta \eta$ i $\mu \hat{\imath} \nu$ uitgedruk (Robertson 1930:61; vgl Marguerat 2002:173; Kistemaker 1990:185-186, 190). Saffira se skuld blyk ook duidelik uit die wyse waarop sy Petrus in vers 8 antwoord (Marguerat 2002:174; Witherington III 1998:217-218; Kistemaker 1990:187; Haenchen 1971:238-239). Die drie voorkomste van $\sigma \grave{v} v$ en twee voorkomste

\footnotetext{
${ }^{2}$ Volgens Reimer (1995:23) sinspeel die Griekse $\Sigma \alpha \pi \phi i ́ p \eta$ hier waarskynlik op die Hebreeuse woord Hierdie Hebreeuse woord verwys veral na wetsdokumente (Whitaker 1997 s v ספר). Volgens Reimer (1995:23) word die naam waarskynlik eksplisiet genoem om 'n wettige ooreenkoms tussen Saffira en haar man te veronderstel, by name die Judese wet op privaat eiendom. Meeste kommentatore meen egter dat haar naam slegs "mooi" beteken. Dit is onnodig om 'n saak vir betrokkenheid van Saffira by die bedrog op grond van etimologiese of linguïstiese argumente uit te maak, aangesien haar betrokkenheid (soos ons sal sien) eksplisiet in die teks genoem word.

${ }^{3}$ Die teks verwys moontlik na 'n sekere Judese wet, naamlik die wet op privaat eiendom, en veral huwelikseiendom (kyk Witherington 1998:215). Daarvolgens word elke vrou wanneer sy trou in 'n huwelikskontrak deur haar man 'n spesifieke hoeveelheid geld verseker mits hulle skei (Reimer 1995:23). Alle eiendom behoort aan die man, maar as hulle skei kry die vrou hierdie voorafbepaalde hoeveelheid geld. As gevolg van hierdie huwelikskontrak is enige koop of verkoop van die man se eiendom afhanklik van en onderhewig aan die vrou se toestemming (Reimer 1995:23). Indien die vrou instem tot die verkoop van eiendom, moet sy dit in die openbaar aankondig, waartydens sy haar reg op die voorafbepaalde som geld opgee (Reimer 1995:23). Dit is moontlik wat Lukas meen het gebeur wanneer hy in Handelinge 5:1 sê dat Ananias en Saffira 'n eiendom verkoop het. Daar is egter geen direkte verwysing na hierdie wet in die teks nie (Witherington 1998:215). Die betrokkenheid en skuld van albei antagoniste is (soos ons sal sien) duidelik genoeg sonder dat hierdie wet in die Sitzim-Leben van die narratief ' $\mathrm{n}$ rol speel.
} 


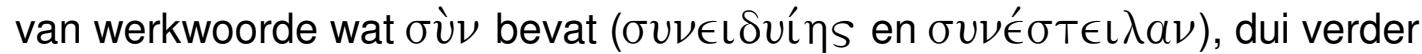
die eggenote se gesamentlike skuld aan (Marguerat 2002:174; Witherington III 1998:218). Dit is nie seker of die name "Saffira" en "Ananias" na historiese persone verwys en of die verhaal in Handelinge 5:1-11 op werklike gebeure teruggaan nie (vgl Barrett 1994:263-264).

Die twee se dood is 'n resultaat van hulle ongehoorsaamheid (vgl Hand 5:5, 10) (Reimer 1995:24; Beck 1990:291). Lukas probeer 'n norm vir sy lesers stel: moenie oneerlik wees in julle handelinge met die kerk nie (Reimer 1995:24; Barrett 1994:262)! Saffira sterf omdat sy ongehoorsaam was, nie omdat sy 'n vrou was nie (Beck 1990:291). In hierdie storie word daar vir vroue 'n geleentheid geskep waartydens hulle die patriargale strukture van hulle tyd kan ondermyn (Reimer 1995:24; Martin 1994:779-780). Hulle mag en moet hulleself distansieer van enige korrupte besluite van hulle mans (Reimer 1995:24). Die bevryding van vroue is egter slegs gedeeltelik, aangesien hulle nie in die alledaagse kom en gaan kan wegbreek van die patriargale strukture nie, maar slegs as die patriarg oneerlik is teenoor die kerk. Die Jesusbeweging se belange is vir Lukas primêr, wat beteken dat die ekklesiale strukture volgens hom meer gewig as die vorige patriargale strukture dra. Hierdie perikoop onderskryf die vroeë gelykheid tussen geslagte, maar verklap niks oor die leiersposisie van vroue in die eerste-eeuse kerk nie.

'n Aspek van hierdie verhaal wat gewoonlik misgekyk word, is die sosiale klas waarin Saffira haarself bevind. Sy word geskets as ' $n$ vrou wat deel was van 'n huwelik waar beide partye gesamentlik ' $n$ taamlike groot finansiële bydrae tot die geloofsgemeenskap kon maak (Martin 1994:780). Verder word die huwelik as 'n verhouding van gelykes uitgebeeld. Haar bydrae in die bedrog word beklemtoon, wat beteken dat haar relatiewe outonomie beklemtoon word.

\subsection{Weduwees}

Handelinge 6:1-7 vertel hoedat daar klagtes vanaf die Griekse Christene ingekom het dat die Hebreeussprekende Christene die weduwees in die daaglikse versorging afskeep. Hierdie probleem is opgelos deur sewe mans vir die taak af te vaardig. Uit hierdie gedeelte kan ons agterkom dat die vroeë kerk moeite gedoen het om die gemarginaliseerde weduwees te versorg. Alhoewel die afgevaardigde versorgers slegs uit mans bestaan het, was die behoeftes van die weduwees belangrik genoeg vir die beweging om hulle behoeftes onder die aandag van die twaalf apostels te bring (Tucker \& Liefeld 1987:66). Afgesien van die bogenoemde historiese perspektief, is daar ook 'n sosiologiese invalshoek op die gebeure van Handelinge 6:1-7. Onder die sewe uitgesoekte mans verskyn ook die name van twee van die mees 
prominente predikers en leermeesters van die vroeë kerk (Witherington III 1988:145). Hulle is Stefanus en Filippus (Hand 6:5). Die sewe mans se taak

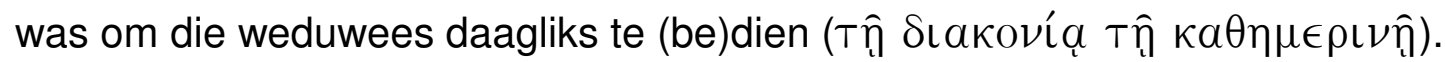

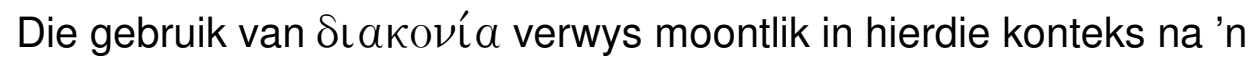
gespesialiseerde diakoniese bediening (Martin 1994:781). Hierdie lees van die teks word deur die woord $\chi \rho \in$ ías in vers 3 ondersteun (vgl Haenchen

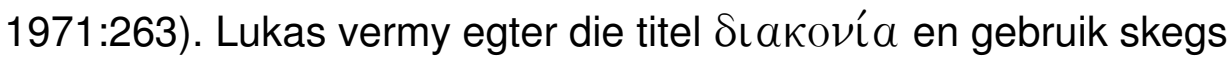
verbuigings daarvan (Dunn 1996:83; Kistemaker 1990:222; Bruce 1976:152; Haenchen 1971:262), wat 'n alternatiewe verstaan van vers 3 moontlik maak.

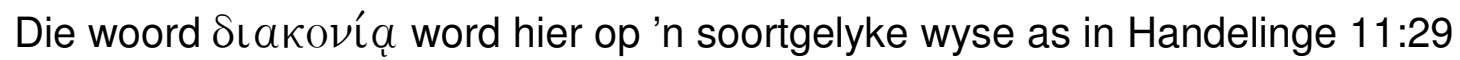
en 12:25 aangewend, waar dit na die praktiese versorging van fisiese behoeftes verwys (Barrett 1994:310; kyk Robertson 1930:73). Dieselfde word

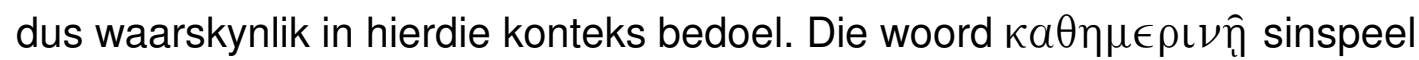
op die gebruiklik-Judese versorging van armes (Barrett 1994:310; vgl Martin 1994:781). Hierdie versorging het hoofsaaklik uit die (daaglikse) verskaffing van voedsel bestaan (kyk Barrett 1994:310; Robertson 1930:73). Die primêre betekenis van $\tau \rho a \pi \epsilon ́ \zeta$ als in vers 2 is "tafel" (meestal 'n "etenstafel") (Barrett

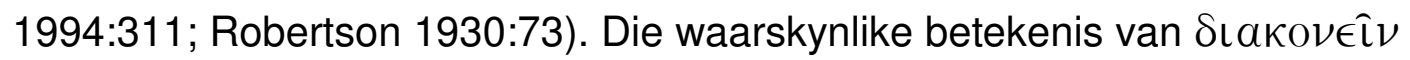
тратє́) $\zeta$ als is dus om te "dien by 'n (etens)tafel", wat beteken om voedsel aan die weduwees te voorsien (Barrett 1994:311; vgl Witherington III 1998:249; Bruce 1976:152). In die patriargale samelewing van die antieke tyd was dit ongehoord vir 'n man om 'n vrou te dien, wat nog te sê 'n weduwee. In hierdie gedeelte word die patriargale hiërargie dus op sy kop gekeer. Witherington III (1998:248) noem hierdie fenomeen "the first example of affirmative action." Hiermee onderskryf Lukas sy egalitêre ideologie (kyk Kistemaker 1990:783).

In hierdie perikoop handel dit egter nie in die eerste plek oor die weduwees nie, maar oor die instelling van die bediening waaraan die sewe mans deel het (kyk Barrett 1994:305-306; Martin 1994:780; Jervell 1984:153). Die weduwees en hulle behoeftes word vinnig eenkant geskuif (Barrett 1994:306; vgl Jervell 1984:153). Die sewe mans is van vers 3 af reeds in die kollig. Die weduwees is slegs passiewe ontvangers van die welsyn (Martin 1994:781). Tog word al die reëlings ten gunste en ter wille van die weduwees getref. Afhangende van 'n leser se vooronderstelling, kan hierdie perikoop óf gelees word as ' $n$ androsentriese onderdrukking van vroue se reg om leiding te neem en aktief by die kerk betrokke te wees, óf as 'n radikale verbreking van patriargale konvensies deur belangrike mans uit te kies om na onbenullige vroue se daaglikse behoeftes om te sien. Ek kies die tweede opsie. Hier word geen woord gerep oor 'n lys van weduwees of sekere voorwaardes om as weduwee te kwalifiseer nie, wat beteken dat hierdie 
perikoop 'n meer primitiewe vorm van die weduwee-bediening as in 1 Timoteus 5 verteenwoordig (Jervell 1984:153; Stagg \& Stagg 1978:229; vgl Barrett 1994:310; Williams 1964:96). Hierdie gedeelte sê dus nie veel oor die posisie van vroue in die vroeë kerk nie.

\subsection{Tabita}

In Handelinge 9:36 skryf Lukas die volgende: "In Joppe was daar 'n gelowige vrou met die naam Tabita, in Grieks Dorkas. Sy was altyd besig om goed te doen en die armes te help" (NAB). Die woord wat hierbo met "gelowige vrou"

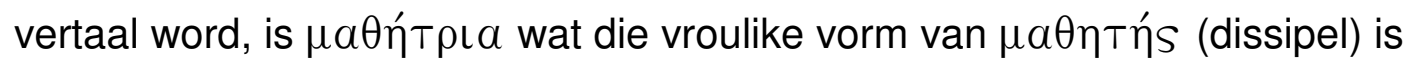
(Barrett 1994:482; Kistemaker 1990:364; Witherington III 1988:150; Tucker \&

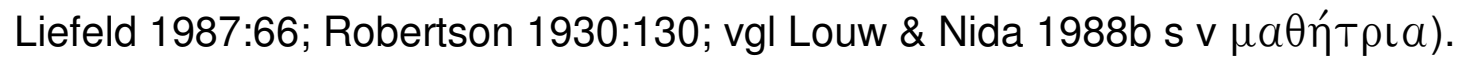
Tabita was dus 'n vroulike dissipel (Witherington III 1998:331; Reimer 1995:61, 262; Martin 1994:782; Witherington III 1988:150). Die term $\mu a \theta \eta ́$ рı $а$ kom nêrens anders in die Nuwe Testament voor nie (Witherington III 1998:331; Martin 1994:782; Beck 1990:301; Kistemaker 1990:364;

Witherington III 1988:150; Bruce 1976:212; Haenchen 1971:338-339; Williams 1964:129; Robertson 1930:130). Sy het haar dissipelskap uitgeleef deur goed te doen en armes te help (Barrett 1994:483; Beck 1990:297, 301; Kistemaker 1990:360; vgl D’Angelo 2002:51; Reimer 1995:61, 262). Dit impliseer dat sy oor genoeg hulpbronne beskik het om armes mee te kon help (Witherington III 1998:331; Arlandson 1997:144; Kistemaker 1990:360). Sy was dus waarskynlik wel-af (Arlandson 1997:144). Haar naam word in sowel Grieks as Aramees gegee, wat enersyds beteken dat sy deel van 'n tweetalige gemeente was, maar andersyds waarskynlik iets oor haar prominensie in die gemeente sê (Tucker \& Liefeld 1987:66). Sy was bekend by beide faksies in die gemeente. Lukas noem vroue slegs op hulle name indien hulle uitsonderlike persoonlikhede was en 'n blywende invloed op die voortbestaan van die Jesus-beweging gehad het (Arlandson 1997:144; Reimer 1995:259). In vers 37 word vertel hoedat sy as gevolg van siekte gesterf het.

Die weduwees het oor haar gehuil, waarskynlik omdat hulle ook van haar welsyn ontvang het en/of saam met haar gewerk het (kyk Arlandson 1997:144; Reimer 1995:61; Witherington III 1988:150; Stagg \& Stagg 1978:228). Eersgenoemde is meer waarskynlik. Net soos in Handelinge 6:1-7 (par 2.4), verteenwoordig die weduwees in hierdie perikoop ook nie die gespesialiseerde welsynsbediening van 1 Timoteus 5:9-16 nie, maar is hulle die ontvangers van welsyn (Witherington III 1998:333; Barrett 1994:484; Bruce 1976:212; vgl Jervell 1984:153, 156). Tabita se bediening spesifiek aan die weduwees (ai $\chi \hat{\eta} \rho a \iota)$ impliseer 'n deurlopende en gespesialiseerde bediening (Witherington III 1998:333; Witherington III 1988:151; Stagg \& 
Stagg 1978:228; kontra Jervell 1984:153). Haar diens aan die weduwees kan inhoudelik vergelyk word met die werk van die sewe uitgesoekte mans in Handelinge 6:1-7 (vgl par 2.4) (Beck 1990:301; Witherington III 1988:151). Lukas wil Tabita waarskynlik uitbeeld as die leier van die groep weduwees self of die groep wat die weduwees bedien (Witherington III 1988:151; Stagg \& Stagg 1978:228). Hulle dien in die narratief as die getuies van haar goeie werke (Reimer 1995:61). Om meer konkrete bewyse voor te hou as slegs hulle eie getuienis, wys hulle vir Petrus die klere wat sy gemaak het (Reimer 1995:61; Stagg \& Stagg 1978:228; vgl Kistemaker 1990:361; Bruce 1988:199; Haenchen 1971:339). Hierdie klere was waarskynlik deel van die welsynswerk wat sy gedoen het (Arlandson 1997:144; Barrett 1994:484-485; Kistemaker 1990:361; Witherington III 1988:150). Die "klere" in die Nuwe Afrikaanse

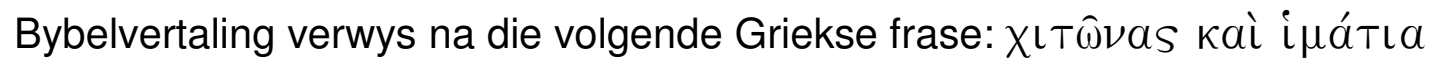
(Reimer 1995:61). Die letterlike vertaling hiervan is: "tunieke en tabberds" of "boklere en onderklere" (Barrett 1994:485; Williams 1964:129; vgl Louw \&

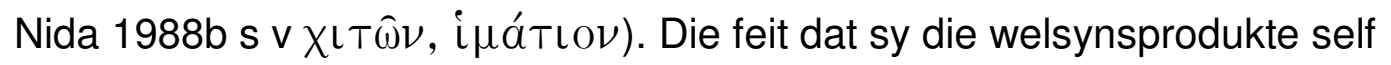
maak, asook die feit dat sy beide bo- en onderklere maak, bewys enersyds hoe toegewyd sy aan haar versorgingswerk was (Reimer 1995:61), en andersyds dat sy wel-af en waarskynlik enkellopend was (Arlandson 1997:144; Witherington III 1988:150-151).

In die res van die perikoop word daar vertel hoedat sy glo weer deur Petrus lewend gemaak word. Petrus se teenwoordigheid gee apostoliese prominensie aan haar lewe (Beck 1990:301). God staaf volgens Reimer (1995:61) die vroue se getuienis deur Tabita uit die dood op te wek. Die wonderwerk is hiervolgens 'n affirmasie van die weduwees se getuienis, en sodoende ook van Tabita se uitstekende dissipelskap (Reimer 1995:61; kyk Barrett 1994:486). Lukas vertel hier van 'n vroulike dissipel wat haar dissipelskap uitgeleef het, geliefd was in haar gemeente en sodoende 'n wonderwerk moontlik gemaak het (Reimer 1995:61; Tucker \& Liefeld 1987:6667; vgl Witherington III 1988:149-151). Sy is die eerste persoon in Handelinge wat deur 'n apostel uit die dood opgewek word (Beck 1990:301). Reimer (1995:262) meen dat Tabita die hoof van die huiskerk in Joppe was. Die

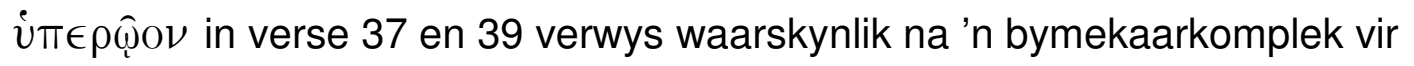
Christene (Barrett 1994:483). Die feit dat haar lyk daar lê, kan ook beteken dat dit haar bokamer was (Witherington III 1998:331-332). Dit sou Reimer se voorstel dat Tabita die hoof van 'n huiskerk was, ondersteun. Alhoewel dit moontlik is, is daar geen direkte bewyse hiervoor in die teks nie.

In Handelinge 9:32-42 doen Petrus twee wonderwerke - een vir 'n man (Hand 9:32-35) en een vir 'n vrou (Hand 9:36-42). Hierdie is dus waarskynlik ' $n$ voorbeeld van Lukas se man-vrou parallellisme (Witherington III 1988:150). 
Die prominensie van Tabita bo Eneas is duidelik. Ons het reeds gesien hoeveel inligting Lukas oor Tabita gee en hoe hy haar prominensie en invloed in die geloofsgemeenskap beklemtoon. Hierteenoor word daar slegs genoem dat Eneas 'n gelowige was (Hand 9:32-33) en dat mense te danke aan sy genesing tot bekering gekom het (Hand 9:35) (Witherington III 1988:150). Lukas noem haar pertinent ' $n$ "dissipel", maar noem vir Eneas slegs 'n "gelowige" (Bruce 1976:212; Kistemaker 1990:364). Teenoor Lukas se belangstelling in Tabita blyk daar geen belangstelling by Lukas te wees wat die persoon van Eneas aanbetref nie, slegs wat sy genesing aanbetref (Witherington III 1988:150). Tabita se verhewe status word nie net in terme van haar persoon beklemtoon nie, maar ook in terme van die genesing self. Waar Eneas van verlamming genees word (Hand 9:33), word Tabita uit die dood opgewek (Hand 9:40-41) (Witherington III 1988:150). Dit is moontlik dat Lukas in hierdie antitese die gesag van ' $n$ vrou in die vroeë kerk bo-oor dié van 'n man wil stel (Witherington III 1988:150). Hierdie Lukaanse motief weerspieël moontlik Tabita se gesagsposisie in haar tuisgemeente. Dit is duidelik dat Tabita nie net ' $n$ prominente en geliefde figuur in haar tuisgemeente was nie, maar ook gesag afgedwing het en 'n belangrike leiersposie beklee het (vgl par 2.4) ( $\mathrm{vgl} \mathrm{Hand} \mathrm{6:1-7).}$

Martin (1994:782) meen dat Tabita se bydrae op twee wyses afgeplat word. Eerstens neem sy deel aan 'n bediening wat slegs op vroue toegespits is. Die sewe mans van Handelinge 6:1-7 se werk was egter ook eksklusief op

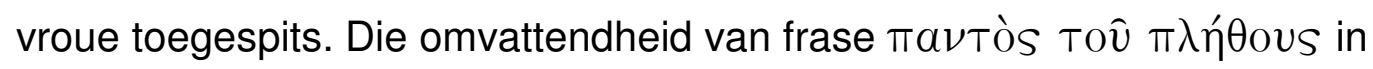
Handelinge 6:5 (vgl Martin 1994:782) verskil nie veel van dieselfde

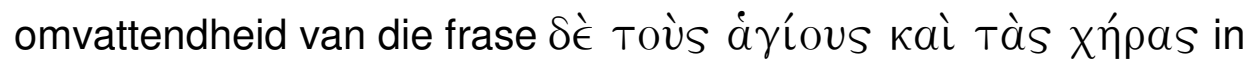
Handelinge 9:41 nie. Tweedens word haar bediening volgens Martin

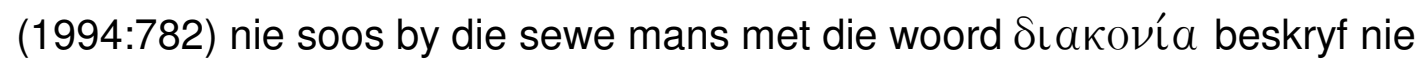

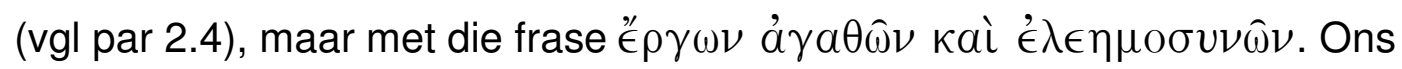
het reeds aangetoon dat Handelinge 6:1-7, ten spyte van die voorkoms van $\delta\llcorner$ aкovía, nie noodwendig ' $\mathrm{n}$ formele of gespesialiseerde bediening in gedagte het nie (vgl par 2.4). Maar selfs al sou dit die geval wees, het ons ook gesien dat Tabita se bediening nie minder gespesialiseerd was nie. Martin se argumente dra dus nie veel gewig nie en faal daarin om die totale beeld wat hierdie perikoop van Tabita skets, in ag te neem.

\subsection{Maria, die ma van Johannes Markus}

In Handelinge 12:12 skryf Lukas die volgende: "Met dié gedagte is hy (Petrus) na die huis van Maria, die moeder van Johannes wat ook Markus genoem is, waar baie gelowiges saam was om te bid" (NAB). Maria word hier uitgebeeld as die eienaar van 'n huis waar gelowiges bymekaargekom het (D'Angelo 
2002:51; Malone 2001:69; Witherington III 1998:386; Arlandson 1997:138; Beck 1990:295; Witherington III 1988:146). Dit beteken dat sy daardie huiskerk gestig het en as weldoener vir die geloofsgemeenskap optree ( $\mathrm{vgl}$ par 1) (vgl Witherington III 1998:338). Die huiskerk word uitgebeeld as 'n plek

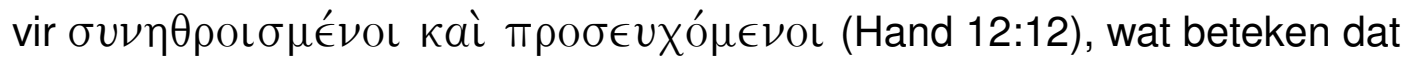
Christene gereeld daar bymekaargekom het (Witherington III 1998:386-387; Arlandson 1997:138; Witherington III 1988:146-147; vgl Bruce 1976:246-247). Dat Petrus weet waarheen om te gaan en dat hy eerste na Maria se huis gaan om van sy vrylating te vertel, impliseer ook dat die huiskerk 'n gereelde bymekaarkomplek vir Christene was (Witherington III 1998:386-387; Kee 1997:154; Beck 1990:295-296; vgl Barrett 1994:584; Martin 1994:783; kyk Bruce 1988:237). Die feit dat Rodé vir Petrus herken het, suggereer dat hy al voorheen in Maria se huis was (kyk Kistemaker 1990:440). Dit wys ook op die bekendheid van die huiskerk. Maria se verhouding met Johannes Markus word waarskynlik slegs genoem om haar van ander vroue met dieselfde naam af te sonder. Maria was 'n algemene naam in die eerste eeu. Daar is geen rede om aan te neem dat Maria ondergeskik was aan Johannes Markus nie (Beck 1990:295; vgl Bruce 1976:247; kontra Witherington III 1988:146). Die feit dat Lukas geen man of broer van Maria noem nie, is opmerklik (Barrett 1994:583). Verder word Maria, en nie Johannes Markus nie, uitgesonder as die eienaar van die huis (Beck 1990:295).

Maria word hier uitgebeeld as die alleeneienaar van die huis ( $\mathrm{vgl}$ Robertson 1988:169). Hierdie was volgens Malone (2001:69) waarskynlik 'n hellenistiese huiskerk, "... because the focus of the authorities (King Herod) at this time was the persecution of the original Jewish Christian community in Jerusalem." Die huiskerk word verder beskryf as 'n groot gebou, aangesien baie (i $\kappa \alpha \nu \circ)$ ) daarin bymekaar kon kom (Hand 12:12) (Witherington III 1998:386; Arlandson 1997:138; Martin 1994:783; Kistemaker 1990:439; Robertson 1988:169; Witherington III 1988:146). Die huis het ook 'n deur gehad wat waarskynlik na 'n deurgang of stoep gelei het (Tìv $\theta \dot{u} \rho a \nu$ тô $\pi U \lambda(\hat{\nu} \mathrm{OS})$ (Hand 12:13) (Arlandson 1997:138; Barrett 1994:584; Martin 1994:783; Kistemaker 1990:439; Bruce 1988:238; Robertson 1988:170; Witherington III 1988:146). Hierdie stoep herinner aan 'n soortgelyke stoep in die paleis van die hoëpriester (Tòv $\pi v \lambda \hat{\omega} \nu \alpha$ ) (vgl Matt 26:71) (Bruce 1988:238). Die huis het verder 'n diensmeisie ( $\pi a\llcorner\delta i ́ \sigma \kappa \eta)$ genaamd Rodé gehad (Hand 12:13) (Barrett 1994:584; Martin 1994:783; Witherington III 1988:146). Uit al die bogenoemde kan ons aflei dat die huis groot en indrukwekkend was, wat noodwendig beteken dat Maria wel-af was (Witherington III 1998:386; Arlandson 1997:138; Martin 1994:783; Witherington III 1988:146). Lukas noem vroue slegs op hulle name indien 
hulle uitsonderlike persoonlikhede was en 'n blywende invloed op die voortbestaan van die Jesus-beweging gehad het (Reimer 1995:259). Dieselfde moet van Maria veronderstel word. Die feit dat Lukas beskryf hoedat Maria 'n byeenkoms van Christene in Jerusalem akkommodeer op so 'n tyd van akkumulerende teenkanting teen die beweging, bewys dat hy een vrou se heldhaftige bydrae tot die geloofsgemeenskap uitbeeld (Arlandson 1997:139; Witherington III 1988:147).

\section{$2.7 \quad$ Lidia}

In Handelinge 16:14 vertel Lukas hoedat 'n vrou in Filippi tot bekering gekom het. 'n Vrou word hier geskets as Paulus se eerste bekeerling in Europa (Bruce 1988:311; kyk Matson 1996:150; Martin 1994:784). Paulus huiwer nie om 'n groep heidense vroue met die evangelie te nader nie (Beck 1990:292$293,302)$. Paulus het haar en die vroue saam met haar op die Sabbat by 'n Judese bidplek ( $\pi \rho \circ \sigma \epsilon v \chi \eta े \nu)$ ontmoet. Nadat sy na Paulus se prediking geluister het, is sy en haar huigesin gedoop (Hand 16:15). Die frase TIS

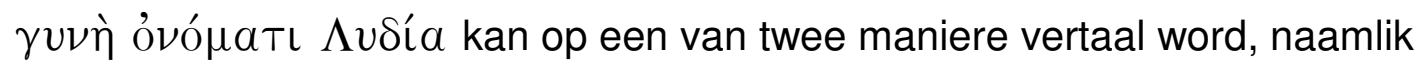
"'n vrou met die naam Lidia" of "'n vrou vanuit Lidia" (Matson 1996:143; vgl Kistemaker 1990:589; Bruce 1976:314). In vers 14 noem Lukas dat hierdie vrou met pers wolmateriaal handel gedryf het. Sy was afkomstig van Tiatira, wat in die distrik van "Lidia" geleë was (Witherington III 1998:491; Kistemaker 1990:589; Bruce 1988:311; Haenchen 1971:499; Williams 1964:194). Die mense van daardie omgewing was bekend vir die vervaardiging van pers kleursel (Matson 1996:143; Bruce 1988:311; Haenchen 1971:499; Williams 1964:194; Robertson 1930:251-252). Daar is dus een van twee opsies: óf die eienaam "Lidia" is 'n sinspeling op hierdie antieke distrik, óf die vrou wat vanuit die distrik "Lidia" kom se naam is onbekend. Die eerste opsie is meer waarskynlik. Die gebruik van óvó $\mu a \tau ı$ maak van "Lidia” 'n eienaam (Haenchen 1971:494), aangesien dit die eenvoudigste verstaan van die Grieks is (Witherington III 1998:491).

Nietemin, die vervaardiging van wolmateriaal impliseer dat sy meer as net finansieel onafhanklik was (Malone 2001:70; Haenchen 1971:494). Die produksie van gekleurde wolmateriaal was in Filippi van groot kommersiële belang (Reimer 1995:263; Tucker \& Liefeld 1987:68; Robertson 1930:252). Sy was dus nie net ryk nie, maar 'n vrou met invloed en 'n noemenswaardige reputasie in die stad Filippi (Witherington III 1998:492; Arlandson 1997:140; Matson 1996:143; Beck 1990:302; Kistemaker 1990:590; Tucker \& Liefeld

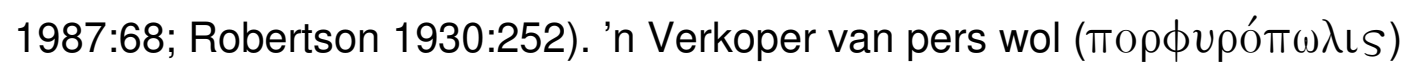
was iemand wat met rykdom, welvaart, 'n gemaklike leefstyl en die vervaardiging van koninklike klere geassosieer is (Arlandson 1997:140; vgl 
Robertson 1930:252). Persone moes ryk wees om by hierdie bedryf ' $n$ voet in die deur te kry (Arlandson 1997:140). Net konings en die baie ryk mense van groot stede kon pers klere bekostig (vgl Dan 5:7; Luk 16:19-31; Mark 15:17) (Arlandson 1997:140; Kee 1997:192; Dunn 1996:219; Kistemaker 1990:590; Haenchen 1971:494). Sy was moontlik selfs deel van die elite (Witherington III 1998:492).

Haar finansiële onafhanklikheid word uitgespel deur die besitlike voornaamwoord "haar" (aùTท̂s) in die frase "haar huisgesin" (ó ổkos aưTท̂s) in vers 15 (vgl Barrett 1998:783). Die afwesigheid van 'n patriarg in haar gesin blyk heel duidelik uit die bogenoemde (D'Angelo 2002:51; Reimer 1995:263; kyk Barrett 1998:783-784; Beck 1990:302; Bruce 1976:314;

Robertson 1930:252). Vroue van Masedonië was bekend vir hulle onafhanklikheid (Bruce 1988:311). Lidia word dus as die hoof van die huis uitgebeeld (Kistemaker 1990:590; Bruce 1976:314; vgl Matson 1996:136). Dit beteken dat sy beslis ook 'n leierskapsposisie in die huiskerk sou vervul het (kontra Martin 1994:784). Lidia se huisgesin het heel moontlik uit beide die (ander) vroue wat by die wolmateriaalbedryf betrokke was (Robertson 1930:253) en haar uitgebreide familie (Witherington III 1998:493; Kistemaker 1990:590) bestaan (Bruce 1976:314). As 'n praktiese bewys van haar opregte geloof en uit dankbaarheid, nooi sy Paulus en sy reisgenote ook uit om by haar tuis te gaan (Witherington III 1998:493; Kistemaker 1990:590; Bruce 1988:311; vgl Beck 1990:302; Haenchen 1971:499). In die eerste plek is dit noemenswaardig dat sy 'n huis besit (Arlandson 1997:140). Daar word nie een woord oor die toestemming van 'n eggenoot of die bestaan van 'n patriarg geuiter nie. Verder impliseer die uitnodiging dat daar genoeg akkomodasie vir die inwoners, Paulus en sy reisgenote in haar huis was (Dunn 1996:219; Matson 1996:143-144). Uit die bogenoemde kan ons aflei dat Lidia 'n vrou was wat sonder 'n eggenoot in 'n groterige huis gelewe het, en finansieel onafhanklik was (vgl Dunn 1996:219; Matson 1996:144). In vers 14 word sy 'n

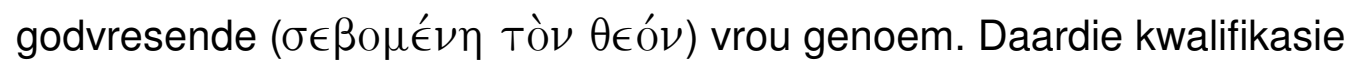
( $\sigma \epsilon \beta о \mu \epsilon ́ \nu \eta$ Tò $\theta \epsilon o ́ \nu)$ verwys gewoonlik na diaspora Judeërs, wat in een God glo en die Judese godsdienspraktyke so getrou moontlik probeer nakom (Malone 2001:70; Reimer 1995:262; Tucker \& Liefeld 1987:68-69). Na hulle verblyf in Lidia se huis, het Paulus en Silas in die tronk beland, maar hulle het glo deur wonderbaarlike gebeure vrygekom (Hand 16:16-39). Daarna keer hulle terug na Lidia se huis, waar sy alreeds haar eie huiskerk begin het (Hand 16:40) (kyk Barrett 1998:805; Arlandson 1997:140; Matson 1996:149; Witherington III 1988:146, 149; Tucker \& Liefeld 1987:69). Daar het sy waarskynlik as 'n leier opgetree (Dunn 1996:219). Volgens Reimer (1995:263) en Arlandson (1997:140) het Lidia se huiskerk die sentrum en basis van 
Paulus se sendingwerk in Filippi geword. Witherington III (1988:149) gaan nog 'n stap verder: "Luke wishes us to understand that what began as a lodging for missionaries, became the home of the embryonic church in Philippi" (vgl ook Kistemaker 1990:590). Hy ondersteun hierdie stelling met die argument dat Paulus na sy ontsnapping uit die tronk na Lidia se huis gaan om die gelowiges te bemoedig, en nie na die tronkbewaarder se huis nie (vgl ook Beck 1990:303; Haenchen 1971:495). Beck (1990:302) sien die huiskerk van Lidia ook as die ontstaansplek van die kerk in Filippi, maar gaan nog 'n stap verder deur Filippi te sien as die sentrum van waar die vroeë kerk regdeur Europa versprei het. Paulus sien geen probleem daarmee om 'n nuwe huiskerk in die beheer van 'n vrou te laat nie (Beck 1990:293).

Net soos in die geval van Dionisius en Damaris (vgl par 2.2) gebruik Lukas waarskynlik hier ook twee persone van teenoorgestelde geslag as verteenwoordigend vir almal wat in Filippi gelowig geword het (Witherington III 1988:147-148). Lidia is dus die vroulike teenhanger van die tronkbewaarder wat in Handelinge 16:23-39 die evangelie aangeneem het (Martin 1994:778). Die verband tussen Lidia en die tronkbewaarder word versterk deur die

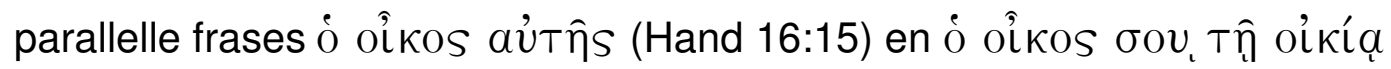
aủTố (Hand 16:31, 32, 34). Lidia se prominensie bo die tronkbewaarder word egter op meer as een geleentheid uitgewys. Eerstens kom Lidia eerste in die verhaal voor (Hand 16:12-15). Sy word dus uitgesonder as die eerste bekeerling in Filippi (Witherington III 1988:149). Asof dit nie genoeg is nie, sluit Lukas tweedens die verhaal in vers 40 met haar af. Dit vorm 'n tipe vroulike inklusio. In die derde plek word Lidia op haar naam genoem, terwyl die tronkbewaarder anoniem bly. Laastens begin Lidia 'n huiskerk, terwyl daar niks van die tronkbewaarder se betrokkenheid by die verspreiding van die evangelie gesê word nie. Die waarskynlikheid dat Lidia en die tronkbewaarder verteenwoordigend van die geloofsgemeenskap in Filippi is, open die moontlikheid dat Lukas hier die verhewe posisie van vroue in die ontstaan van die geloofsgemeenskap in Filippi suggereer.

Die feit dat die Sabbat pertinent in vers 13 genoem word, asook die feit dat Paulus vir Lidia en die vroue by 'n Judese bidplek ontmoet, sinspeel waarskynlik op die nuwe rol van vroue in die Jesus-beweging (Witherington III 1988:148). Die marginalisering van vroue in die Judese sinagoge word antiteties teenoor hulle nuwe rol in die vroeë kerk gestel (Witherington III 1988:148). Dit is veral verse 13 en 40 wat teenoor mekaar gestel word en 'n antitetiese inklusio van die gedeelte vorm (Witherington III 1988:148). Die beperkte invloed en betrokkenheid van vroue in die antieke sinagoge word met die leierskap en noodsaaklikheid van vroue in die ontstaan van die Jesusbeweging gekontrasteer. 


\subsection{Vooraanstaande vroue}

In beide Tessalonika en Berea was daar 'n oproer en het nuwe mense by die na-Pase Jesus-beweging aangesluit (Hand 17:1-15). Van diegene in Tessalonika word daar gesê: "'n Groot aantal godvresende Grieke en 'n aansienlike getal vooraanstaande vroue het ook nog bygekom" (Hand 17:4 NAB). Dit is morfologies moontlik om $\pi \rho \omega ́ \tau \omega \nu$ met "vooraanstaande mans" te vertaal, wat tot gevolg sou hê dat vers 4 só lyk: " $n$ Groot aantal godvresende Grieke en 'n aansienlike getal vroue van vooraanstaande mans het ook nog bygekom" (Kistemaker 1990:614; Bruce 1976:325; Williams 1964:198). Die sintaksis maak so 'n vertaling egter onwaarskynlik, aangesien die twee frases 'n chiasme vorm ${ }^{4}$. Verder maak die prominensie van baie Hellenistiese vroue die eerste van die twee boonste vertalings meer waarskynlik (Kistemaker 1990:614; kyk Witherington III 1998:335-336). Die Griekse frase wat met "n aansienlike getal" vertaal word, is oủ ỏ $\lambda i ́$ yaı wat letterlik "[hulle] was nie min nie" beteken (Robertson 1930:269). Hierdie frase is waarskynlik as 'n litotes bedoel (Kistemaker 1990:614; Bruce 1976:325). Die Griekse woord vir "vooraanstaande" is $\pi \rho \omega ́ t \omega \nu$ (Barrett 1998:812). Hierdie Griekse woord het die volgende betekenismoontlikhede: "eerste", "vorige/voorheen", "prominent", "beste" en "belangrikste" (Louw \& Nida 1988b s v $\pi \rho \hat{T} T$ OS). Een van die laaste drie betekenismoontlikhede word beslis hier bedoel (kyk Witherington III 1998:506; Kistemaker 1990:615). Die derde betekenismoontlikheid is "prominent", en word deur Louw \& Nida (1988a:738) as volg omskryf: “... pertaining to being of high rank, with the implication of special prominence and status." Die vierde betekenismoontlikheid is "beste" en word deur Louw \& Nida (1988a:738) beskryf as: "... pertaining to being superior in value to all other items of the same class." Die vierde en vyfde betekenismoontlikhede kom basies op dieselfde neer (Louw \& Nida 1988a:626). Alhoewel hierdie twee betekenismoontlikhede spesifiek by objekte van toepassing is, is die nuanse daarvan steeds belangrik in die konteks van Handelinge 17:4. Die implikasie is dat die vroue wat "bygekom het" in waarde en status verhewe was bo meeste van die ander vroue in Tessalonika (vgl Robertson 1930:269). Die prominente posisie en status van die nuwe Christenvroue word dus in 'n besondere mate deur die woordkeuse in vers 4 uitgewys. Die feit dat daar van die vroue gesê word dat hulle "prominent" was, terwyl die byvoeglike naamwoord wat die Grieke beskryf slegs "godvresend" is, beklemtoon die prominensie van die betrokke vroue nog meer. Soos ons reeds gesien het, was die onafhanklikheid en enterpreneurskap van Masedoniese vroue welbekend (Bruce 1988:323; vgl Robertson 1930:269). Dit is dus waarskynlik

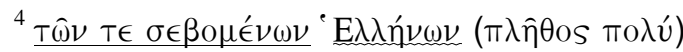

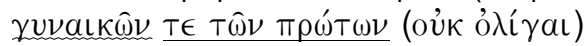


dat die vroue pertinent genoem word omdat hulle bekering 'n resultaat van hulle eie keuse was, nie hulle eggenote s'n nie (vgl Bruce 1988:323).

Chariton (in Reardon 1989:22, 41, 43, 49) noem vir Dionusos die "eerste man" ( $\pi \rho \omega ́$ TOS) van Milete en vir Hermokrates die "eerste man" ( $\pi \rho \omega ́$ Tos) van Sirakuse (Arlandson 1997:129). In Handelinge 28:7 word Publius die "eerste

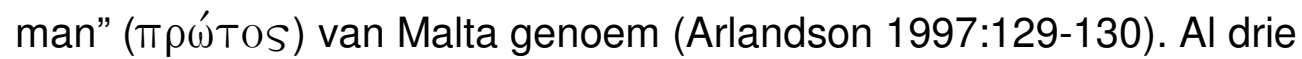
bogenoemde mans was vreeslik ryk, invloedryk en hoog geag (Arlandson 1997:130). Hierdie eksterne getuienis ondersteun die leksikografiese bewyse hierbo, naamlik dat die "vooraanstaande/eerste vroue" van Handelinge 17:4, 12 "... are wealthy ... and that they enjoy a high measure of political power and social prestige" (Arlandson 1997:130). Die politiese en sosiale mag wat sulke vroue kon uitoefen is duidelik uit Handelinge 13:50, waar Paulus en

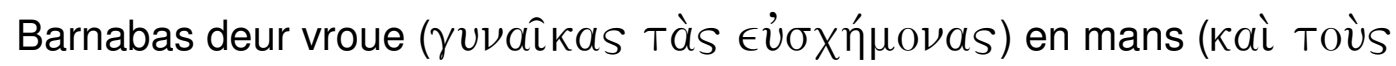
$\pi \rho(\dot{T}$ ous) van dieselfde sosiale status "vervolg word en uit die streek gedrywe word" (Arlandson 1997:130). Die Judeërs van Antiogië het hierdie mense "opgesweep" om te doen wat hulle self nie kon nie, naamlik om die evangeliste uit die gebied te dryf (Hand 13:50).

Dieselfde word ook van die bekeerlinge in Berea gesê: "Baie van die Jode het gelowig geword en ook heelparty van die Grieke, mans sowel as vooraanstaande vroue" (Hand 17:12 - NAB). Hier word 'n ander Griekse woord met "vooraanstaande" vertaal, naamlik $\in \hat{v} \sigma \chi \eta \mu o ́ v \omega \nu$. Hierdie woord beteken "aanvaarbaar", "geskik", "welvoeglik" of "ordentlik". Die implikasie is dat die betrokke vroue Lukas se goedkeuring wegdra. Waar die Griekse mans van Tessalonika "godvresend" genoem word, word die Judese en Griekse mans van Berea glad nie gekwalifiseer nie (Witherington III 1988:144;

Robertson 1930:275). Van die vroue word daar egter gesê dat hulle "geskik" was. Die implikasie van al die bogenoemde is dat die vroue "gerespekteer" is (D’Angelo 2002:67). Hulle was respektabele vroue (D'Angelo 2002:67). Die "gespekteerde vroue" word waarskynlik ingesluit by "die mense" (oû́Tol) van vers 11, wat volgens Lukas "met groot belangstelling na die woord geluister en elke dag die Skrif ondersoek het" (Witherington III 1988:144). Indien die bogenoemde voorstel gewig dra, beteken dit dat vroue deelgeneem het aan die lees en bestudering van die Tanak, iets wat deur Judeërs verbied was (Witherington III 1988:144). Die moontlikheid dat Lukas die vroue in hierdie gedeelte bo die mans uitlig, word ondersteun deur latere tekstuele aanpassings bedoel om die vroue na 'n sekondêre posisie te skuif (vgl Barrett 1998:818-819; Kistemaker 1990:623; Bruce 1976:329; Haenchen 1971:508; Williams 1964:199; kyk Witherington III 1998:506; Beck 1990:283). Bruce (1988:328) meen dat die vroue van vers 12 deel van gesogte families was. Daar is egter geen direkte bewyse hiervoor in die teks nie. 


\subsection{Priscilla en Akwila}

Aan die einde van Paulus se tweede sendingreis het hy by die Korintiese huiskerk van Priscilla ${ }^{5}$ en Akwila aangesluit (Hand 18:1-3). Daar het Paulus saam met hulle in hulle werkswinkel tente gemaak (Hand 18:1-3). Priscilla en Akwila is te same met ander volgelinge van Jesus deur keiser Claudius uit Rome geban (Hand 18:2) (Malone 2001:69; Arlandson 1997:145; Reimer 1995:251; Tucker \& Liefeld 1987:69; Stagg \& Stagg 1978:230). Hulle name is die vroegste eiename wat met betrekking tot die kerk in Rome aan ons bekend is (Malone 2001:69). Dit blyk ook asof hulle voor Paulus reeds Christene was (kyk Witherington III 1998:545; Dunn 1996:241; Kistemaker 1990:649). Later vergesel hulle Paulus na Sirië (Hand 18:18) (Malone 2001:69; Kee 1997:220; Tucker \& Liefeld 1987:67-68). Hulle bly in Efese agter (Hand 18:19), waarskynlik om die geloofsgemeenskap daar op die been te bring (Witherington III 1998:558; Kistemaker 1990:663). Dit wil dus lyk asof ons hier te doen het met 'n sendingpaar, bestaande uit 'n man en 'n vrou, wie se primêre bediening bestaan het uit die neem van leiding waar hulle ookal kom (Malone 2001:69; Martin 1994:785; Tucker \& Liefeld 1987:57). Malone (2001:69) meen dat hulle huiskerke in Rome, Korinte en Efese gestig het. Daar is in hierdie gedeelte slegs bewyse dat Priscilla en Akwila 'n huiskerk in Korinte gestig het (Hand 18:3). Dit is waarskynlik dat hulle dieselfde in Efese gedoen het (Küng 2001:11). Die twee eggenote werk saam as 'n gelyke span in die verkondiging van die evangelie (Martin 1994:796).

In 1 Korintiërs 16:19 kry ons weer met hulle te doen: "Die gemeentes van die provinsie Asië stuur vir julle groete. Van Akwila en Priscilla en ook van die gemeente wat gereeld in hulle huis bymekaarkom: baie groete in die Here" (1 Kor 16:19 - NAB). Die feit dat Paulus vanaf Akwila en Priscilla aan die Korintiese gemeente groete stuur, beteken dat beide Paulus en die Korintiese gemeente met hierdie persone bekend was, en dat Paulus hiervan bewus was. Dit bevestig dus die stelling in Handelinge 18:1-3 dat hulle in Korinte aan Paulus akkomodasie gebied het (vgl Dunn 1996:241). Die boonste vers noem ook pertinent dat Priscilla en Akwila die leiers was van 'n huiskerk (Martin 1994:785; Tucker \& Liefeld 1987:57). Hulle was dus betrokke by die verkondiging van die evangelie en die stigting van huiskerke (vgl Barrett 1998:861). Hulle het waarskynlik hulleself soos Paulus gesien as bringers van

\footnotetext{
${ }^{5}$ Hierdie eienaam word regdeur die NAB met 'Priscilla' vertaal. In Handelinge stem dit wel met die Griekse vorm van die eienaam ( $\left.\operatorname{li}^{\prime} \sigma \kappa \iota \lambda \lambda \alpha\right)$ ooreen (Barrett 1994:861). Paulus gebruik egter die eienaam Прі́бкa om na dieselfde vrou te verwys (Witherington III 1998:538; Barrett 1994:861; Bruce 1976:343). "Priska" is waarskynlik (nader aan) die oorspronklike eienaam, aangesien Paulus kronologies en persoonlik nader aan die betrokke vrou was as Lukas. Dieselfde vrou word met albei eiename bedoel (Barrett 1994:861; vgl Kistemaker 1990:648). Om verwarring te voorkom, gaan ek egter soos die NAB deurgaans van "Priscilla" praat.
} 
die evangelie aan heidennasies. In Romeine 16:3-5 kry ons weer eens met Priscilla en Akwila te doen: "Groete vir Priscilla en Akwila, my medewerkers in Christus Jesus wat hulle lewe vir my gewaag het. Dit is nie net ek wat hulle dankbaar bly nie, maar ook al die gemeentes onder die heidennasies. Groete ook aan die gemeente wat gereeld in hulle huis bymekaarkom" (NAB). In 1 Korintiërs 16:19 stuur Paulus groete vanaf Priscilla en Akwila aan die gemeente in Korinte. In Romeine 16:3-5 stuur hy egter groete aan die twee "medewerkers". In Handelinge kry ons van Priscilla en Akwila ook die algehele indruk van twee medewerkers van Paulus (Witherington III 1998:567; Kee 1997:220; Martin 1994:785; kontra Jervell 1984:155). Priscilla en Akwila bevind hulle dus in Rome wanneer Paulus hierdie brief skryf (Kee 1997:220). Hulle het waarskynlik daarheen teruggekeer toe die stof gaan lê het (Witherington III 1988:116; Bruce 1976:349; vgl Robertson 1930:295). Hulle word in vers 5 uitgesonder as leiers van die huiskerk in Rome (Arlandson 1997:144; Stagg \& Stagg 1978:180; vgl Barrett 1998:863). Die historisiteit van die getroude paar as werklike persoonlikhede wat aan Paulus bekend was en soms aan hom hulp verleen het, hoef op grond van die meervoudige getuienis nie betwyfel te word nie (Barrett 1998:858). Die vermoedens dat hulle 'n huiskerk in Rome gestig het, word ook deur die Pauliniese briewe bevestig (Küng 2001:11; Arlandson 1997:144; Bruce 1988:347; vgl Martin 1994:785;). Dit bring hulle in verband met die stigting van ten minste drie huiskerke, naamlik dié in Efese, Korinte en Rome (Dunn 1996:241; Witherington III 1988:114; kyk Haenchen 1971:538). Hulle vermoë om huiskerke te stig so ver hulle reis, bevestig hulle ekonomiese onafhanklikheid (Arlandson 1997:145; vgl Barrett 1998:863-864; Dunn 1996:241). Die voorlopige stelling dat die sendingpaar moontlik hulleself beskou het as verkondigers van die evangelie aan die heidennasies, word bevestig deur die stelling in vers vier dat dit nie net Paulus is wat aan die twee dankbaar is nie, maar ook "al die gemeentes

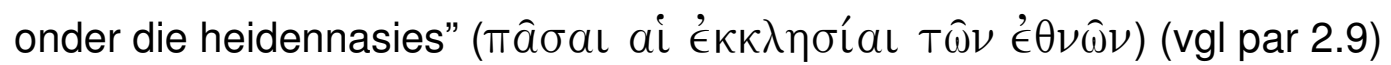
(vgl Barrett 1998:863).

Akwila is uniek in die Nuwe Testament in dat hy nooit sonder sy vrou Priscilla genoem word nie (Barrett 1998:861; Witherington III 1998:539; Beck 1990:303, 304). Volgens Jervell (1984:153) en Beck (1990:304) impliseer die feit dat Priscilla nooit sonder haar man genoem word nie dat sy aan hom onderdanig was. Die werklikheid is egter dat Akwila nooit sonder sy vrou genoem word nie. In die Lukaanse, Pauliniese en Deutero-Pauliniese geskrifte word haar naam in die meeste gevalle eerste genoem (vier uit ses keer in totaal) (vgl Hand 18:18, 26; Rom 16:3; 2 Tim 4:9) (Witherington III 1998:539; Beck 1990:303; Bruce 1988:347-348; Robertson 1930:295; vgl Kistemaker 1990:662-663; Martin 1994:785). Dit impliseer moontlik dat sy 'n 
hoër sosiale klas as haar man geniet het (vgl Bruce 1988:348; Martin 1994:785; Matson 1996:139), of dat sy 'n groter bydrae in die vroeë kerk gemaak het (Kee 1997:223; Williams 1964:209; vgl Kistemaker 1990:663; kontra Jervell 1984:155), of beide (Witherington III 1998:539). Jervell (1984:155) meen dat Akwila "duidelik" teenoor Priscilla die persoon van belang was, maar faal daarin om hierdie stelling te bespreek of bewys. Die feit dat Priscilla deurgaans genoem word, beteken dat sy 'n vooraanstaande en gerespekteerde persoon in haar eie reg moes gewees het (Barrett 1998:861).

Daar is ' $n$ direkte verband tussen hulle prominente posisie by Lukas, Paulus en die gemeentes in Rome, Efese en Korinte enersyds en die feit dat hulle huiskerke gestig het andersyds (Witherington III 1988:110). Hulle stigting van huiskerke, beteken dat hulle waarskynlik nie slegs werkers was nie, maar winkeleienaars (Arlandson 1997:144). Die bokamers en tussenverdiepings van sulke winkels was soms baie groot en ideaal vir die samekoms van gelowiges (Arlandson 1997:144). Priscilla en Akwila het dus aan Paulus (en moontlik ook aan ander) beide 'n werk en 'n blyplek voorsien (Barrett 1998:884; Arlandson 1997:144-145; Dunn 1996:241).

Een van die min uitbeeldings van 'n vroulike leermeester(es) kom in Handelinge 18:24-28 voor (Malone 2001:70). Daar word genoem dat Priscilla en Akwila vir Apollos in die "leer van God" onderrig het (Beck 1990:297). Van hierdie selfde Apollos word gesê dat hy "'n begaafde spreker met 'n deeglike kennis van die Skrif" was (Hand 18:24 - NAB) (Martin 1994:785). Handelinge 18:25-26 gaan nog verder: "Hy het in die leer van die Here onderrig ontvang en het met groot geesdrif gepraat en aan ander noukeurig alles oor Jesus geleer; maar die doop waarvan hy geweet het, was net dié van Johannes. Hy het met vrymoedigheid in die sinagoge begin preek" (NAB). Die verwysing na Aleksandrië as Apollos se geboorteplek is noemenswaardig, aangesien dit gesien is as die geboorteplek van opvoeding, sofisme en retoriek (Arlandson 1997:146; vgl Kistemaker 1990:667; Robertson 1930:306). Ons moet egter versigtig wees om nie te veel in die verwysing na Aleksandrië te lees nie (vgl Barrett 1998:887). Uit die boonste aanhaling kan ons duidelik aflei dat Apollos self 'n intelligente, goed opgevoede en bekwame onderwyser was (Witherington III 1998:564; Dunn 1996:249; Kistemaker 1990:667; vgl Arlandson 1997:145-146; Reimer 1995:265; Witherington III 1988:154; Tucker \& Liefeld 1987:69; Stagg \& Stagg 1978:231). Die "doop van Johannes" impliseer 'n doop van berou, teenoor die Christelike doop met die Heilige Gees (Malone 2001:70; Barrett 1998:888; Kistemaker 1990:668; vgl Bruce 1988:359; Robertson 1930:307). Die feit dat Priscilla en Akwila die leer van God vir hóm "nog duideliker gemaak het", beteken dat hulle gerespekteerde, outentieke en intelligente leiersfigure in die ekklesiale gemeenskap van Efese 
moes gewees het (Malone 2001:70; Witherington III 1998:567; Martin 1994:785). Die werkwoord waarmee hulle onderrig aan Apollos beskryf word ( $\xi \xi \in \in \in \in v T$ ), word in die res van die Nuwe Testament net op die onderrig van Petrus (Hand 11:4) en Paulus (Hand 28:23) van toepassing gemaak (Reimer 1995:265; vgl Moulton \& Geden 1963 s v éK $\tau^{\prime} \theta \in \mu \alpha \mathrm{l}$ ). Dit verwys na 'n uitdagingsvorm en -dialoog wat opbou en uiteindelik duidelikheid bring (Reimer 1995:265). Hierdie oorredingsmetode word aangewend deur diegene wat hulleself reeds in 'n posisie van erkende outoriteit bevind (Reimer 1995:265). Die getroude paar was heel duidelik self ook goed bekend met die inhoud van die evangelie en die leringe van die kerk (Witherington III 1988:154; Tucker \& Liefeld 1987:70). Die volgorde van hulle name in vers 26 suggereer dat Priscilla leiding geneem het in die onderrigting van Apollos (Beck 1990:297; Witherington III 1988:154; Tucker \& Liefeld 1987:69). Hierdie is heel moontlik die enigste geskrewe voorbeeld van 'n vroulike Christenleermeester in amper twintig eeue (Malone 2001:70-71; kyk Reimer 1995:265266). Tog meen Beck (1990:298) dat die ongeërgde wyse waarop Lukas die gebeure in die verbygaan noem, sonder om 'n ophef daarvan te maak, impliseer dat die instruksie van 'n man deur 'n vrou nie 'n ongewone gebruik in die vroeë kerk was nie.

\subsection{Die dogters van Filippus}

In Sesarea het Paulus by 'n bekende evangelis met die naam Filippus tuisgegaan (Hand 21:8). Lukas skryf die volgende oor Filippus: "Hy het vier ongetroude dogters gehad wat die gawe besit het om God se boodskap te verkondig" (Hand 21:9 - NAB). Die boonste frase "die gawe besit het om God se boodskap te verkondig" is in die Griekse teks net een woord, naamlik $\pi \rho \circ \phi \eta \tau \epsilon \dot{0} \sigma \sigma a \mathrm{l}$. Hierdie woord beteken letterlik "profeteer" of "voorspel" (Stagg \& Stagg 1978:231; vgl Louw \& Nida 1988b s v $\pi \rho \circ \phi \eta \tau \epsilon u ́ \omega)$. Die woord kom ook in die partisipium voor, wat beteken dat die vier dogters van Filippus letterlik "profeterende dogters" was (Küng 2001:7; Tucker \& Liefeld 1987:71). Die partisipium toon veral aan dat hulle profetiese gawe 'n voortgaande kwaliteit gehad het (Witherington III 1998:633). Hierdie dogters van Filippus was vir Lukas 'n bewys vir die waardigheid van die Pinkstergebeure, asook dat die profesie van Joël waar geword het (vgl par 2.1) (vgl Hand 2:17) (Barrett 1998:994; Martin 1994:787; Beck 1990:299). Hier kry ons dus met vroue te doen wat spesifiek deur Lukas as begaafde profetesse uitgesonder word (Küng 2001:7; Tucker \& Liefeld 1987:71; vgl Barrett 1998:994). Alhoewel profesie vir alle Christene toeganklik was, word dit hoofsaaklik met sekere leiers geassosieer wat dit as hulle primêre bediening uitgeleef het ( $\mathrm{vgl}$ Rom 12:6; 1 Kor 12:10, 28; 13:2; 14:6; 1 Tes 5:20) 
(Witherington III 1988:152). Volgens Witherington III (1988:152; 1998:632) was die dogters van Filippus waarskynlik deel van so 'n leiersgroep, aangesien hulle (volgens hom) nie net as blote geleentheidsprofete uitgebeeld word nie. In lyn hiermee, verstaan Beck (1990:299), Kistemaker (1990:748) en Robertson (1930:363) die dogters se gawe as 'n omvattende bediening binne die vroeë kerk. Barrett (1994:994) toon egter oortuigend aan dat Lukas 'n nouere verstaan van profesie het as Paulus (vir wie dit prediking ook insluit). Lukas stel meer in die voorspellingselement van profesie as in die omvattende bediening belang (Barrett 1998:994). Hierdie enkele vers sê dus waarskynlik nie veel oor die posisie van vroue in die vroeë kerk nie. Tog meen Beck (1990:299) dat daar uit die gedeelte afgelei kan word dat hierdie vier profetesse nie die uitsondering was nie, aangesien Lukas nie verskonings vir hulle status en teenwoordigheid maak nie (vgl Martin 1996:786). Die feit dat Lukas nie beskryf hoe hulle 'n profesie prakties maak nie (vgl Haenchen 1971:603), beteken hoegenaamd nie dat hulle rol as profetesse vir Lukas minder gewig as manlike profete dra nie (Witherington III 1998:633; kontra Martin 1994:777, 786-787; kontra Jervell 1984:154). Filippus word ook net in die verbygaan genoem, sonder dat hy enigsins optree (vgl Witherington III 1998:633). Dit open die moontlikheid dat Lukas sy inligting oor die vier dogters uit 'n bondige bron (soos 'n dokument van Paulus se reisplan) gekry het (vgl Haenchen 1971:601). Dit sou verklaar waarom hy hulle slegs in die verbygaan noem. Indien Lukas ongemaklik met hulle gawe was, kon die verwysing na hulle bloot uitgelaat het (kyk Witherington III 1998:633). 'n Kyk na Lukas se evangelie toon egter aan dat hy geensins ongemaklik was met vroue as profete nie (vgl Luk 1-2) (vgl Martin 1994:786; kyk Witherington III 1998:632).

\section{GEVOLGTREKKING}

Geleerdes wys soms op sekere aspekte in Handelinge wat 'n reduksie van vroue se rol in die vroeë kerk kan aantoon. Daar word veral op Lukas se androsentriese taalgebruik gewys (kyk Martin 1994:772-773). In al die

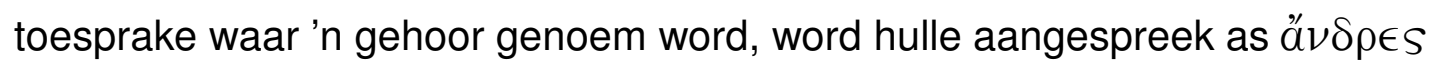
of $\grave{\alpha} \delta \in \lambda \phi o i ́$ (Jervell 1984:151). Dit was egter destyds die gebruik om 'n groep mense in 'n manlike vorm aan te spreek. Verder was á $\delta \in \lambda \phi o i ́$ destyds 'n tegniese term vir die geloofsgemeenskap (Kee 1997:208). Taalgebruik en taalkonvensies is so alledaags dat die dieper betekenisse onbewustelik deur mense gebruik word. Dit is onaanvaarbaar om 'n argument vir androsentrisme op die taalkonvensies van die tyd te baseer. Lukas het waarskynlik die teenwoordigheid van vroue in die geledere van groepe mense en veral die vroeë kerk as vanselfsprekend aanvaar. Daar kan ook nie veel afgelei word 


\section{Handelinge se uitbeelding van die rol van vroue in die vroeë kerk}

uit die feit dat Lukas na slegs een vrou uit die Ou Testament (Hand 7:21) verwys nie (kontra Jervell 1984:155). Om androsentrisme hieruit af te lei sou 'n argument uit stilte wees. Daar is geen bewyse daarvoor dat Lukas met Paulus se briewe bekend was nie. Jervell (1984:156) se voorstel dat Lukas doelbewus oor sekere prominente vroue in Paulus se briewe (byv Rom 16) geswyg het, dra dus geen gewig nie.

Nog 'n argument ten gunste van androsentrisme is dat waar Paulus vroue uitsonder as medewerkers, "sendelinge", ampsdraers en bedienaars van die woord (vgl Rom 16; 1 Kor 16; Fil 4), beskryf Lukas vroue slegs as weldoeners van die kerk (Martin 1994:776; Beck 1990:281; Jervell 1984:152153). Lukas poog egter om 'n fase in die kerk se ontstaan te beskryf waartydens ampte en leiersposisies nog vloeibaar en relatief was. In die 28 hoofstukke van Handelinge verskyn die name van slegs 11 vroue (Beck 1990:282). Drie hiervan is nie-Christene wat geen rol in die uitbreiding van die kerk gespeel het nie (Beck 1990:282). Van die oorblywende agt verskyn slegs vier vroue in meer as een vers, naamlik Saffira, Tabita, Lidia en Priscilla (Beck 1990:282). Vroue word dus slegs in die verbygaan genoem (Beck 1990:282). Op grond hiervan kom Beck (1990:282) tot die volgende konklusie: "The paucity of facts results from the author's androcentric bias and the simple lack of available information." Volgens my is die min verwysings na vroue nie die resultaat van Lukas se androsentrisme nie. Dit is eerder 'n kombinasie van Lukas se doel met die geskrif enersyds en die wyse waarop vroue daarby inskakel andersyds. Lukas poog om 'n kort geskiedenis van die ontstaan en groei van die vroeë kerk te gee. Die feit dat mans se domein buite die huis was, beteken noodwendig dat hulle meer betrokke by die geografiese uitbreiding van die vroeë kerk sou wees (kyk Jervell 1984:156). Lukas vertel dus die gebeure soos hy meen dit plaasgevind het. Waar vroue egter wel 'n belangrike bydrae in hierdie proses gemaak het, skroom Lukas nie om hulle te noem en hulle belang te beklemtoon nie (vgl Witherington III 1998:339). Ten spyte van die klein hoeveelheid verwysings na vroue, gee Lukas steeds “... a systematic portrayal of women's initial involvement in the emergence and growth of the postresurrection church ..." (Martin 1994:771). Waar hulle as weldoeners optree, neem Lukas hulle leierskap as vanselfsprekend aan (vgl par 1). Hoeveelhede kan ons nie veel van vroue se rol in die vroeë kerk of Lukas se siening van vroue wysmaak nie. 'n Meer vrugbare onderneming is om die gevalle waar vroue wel in die geskrif voorkom, te bestudeer.

Dit is wat ons in hierdie artikel gedoen het. In Handelinge word vroue uitgebeeld as ontvangers van die Heilige Gees, aktiewe agente, "sendelinge", getuies, stigters en gasvroue van huiskerke, "onderwysers", versorgers van die armes en profete (Martin 1994:771). Anders as D'Angelo (2002:67) glo ek 
nie dit is nodig om te kies tussen Handelinge as 'n beeld van hoe die vroeë kerk werklik tot stand gekom het, en Handelinge as die ideologie en teologie van Lukas nie. Ek meen dat Handelinge beide op historiese inligting teruggaan en die teologie van Lukas verteenwoordig. Dit is nie altyd maklik om te sien waar die twee oorvleuel en waar ons slegs met een van die twee te doen het nie. Tog is dit noodsaaklik om te aanvaar dat Handelinge ons beide van die rol van vroue in die ontstaan van die Jesus-beweging voor $70 \mathrm{nC}$ en die (gewenste of werklike?) rol van vroue in die plaaslike Lukaanse gemeente na $70 \mathrm{nC}$ vertel. Wat eersgenoemde betref, was dit uit ons ondersoek duidelik dat vroue wel leiersposisies in die vroeë kerk vervul het, veral in die verskaffing en bestuur van huiskerke. Die holistiese beeld wat Lukas van vroue se rol in die vroeë kerk skets, is dus in hierdie studie van meer belang as die normatiwiteit of historisiteit van enige enkele perikoop (kyk Beck 1990:284).

\section{Literatuurverwysings}

Arlandson, J M 1997. Women, class, and society in early Christianity: Models from Luke-Acts. Massachusetts, MA: Hendrickson.

Barrett, C K 1994. A critical and exegetical commentary on The Acts of the Apostles, vol I. Edinburgh: T\&T Clark. (The international critical commentary on the Holy Scriptures of the Old and New Testaments.)

Barrett, C K 1998. A critical and exegetical commentary on The Acts of the Apostles, vol II. Edinburgh: T\&T Clark. (The international critical commentary on the Holy Scriptures of the Old and New Testaments.)

Beck, R 1990. The women of Acts: Foremothers of the Christian church, in Keathley, With steadfast purpose: Essays on Acts in honor of Henry Jackson Flanders, $J$ r. Waco, TX: Baylor University Press.

Bruce, F F 1976. The Acts of the Apostles: The Greek text with introduction and commentary. Leicester: Inter-Varsity.

Bruce, F F 1988. The book of the Acts, rev ed. Grand Rapids, MI: Eerdmans. (The new international commentary on the New Testament).

D'Angelo, M R 2002. The ANHP question in Luke-Acts, in Levine \& Blickenstaff, $A$ feminist companion to Luke. Londen: Sheffield.

Dunn, J D G 1996. The Acts of the Apostles. Peterborough: Epworth. (Epworth Commentaries.)

Haenchen, E 1971. The Acts of the Apostles: A commentary. Oxford: Blackwell.

Holladay, W E 1971. A concise Hebrew and Aramaic lexicon of the Old Testament. Leiden: Brill.

Jervell, J 1984. The unknown Paul: Essays on Luke-Acts and early Christian History. Minneapolis, MN: Augsburg.

Kee, H C 1997. To every nation under heaven: The Acts of the Apostles. Harrisburg, PA: Trinity. (The New Testament in context.)

Kistemaker, S J 1990. Exposition of the Acts of the Apostles. Grand Rapids, MI: Baker Book House. (New Testament Commentary.)

Küng, H 2001. Women in Christianity. New York: Continuum. 
Louw, J P \& Nida, E A (eds) 1988a. Greek-English lexicon of the New Testament based on semantic domains, vol 1. Cape Town: Bible Society of South Africa.

Louw, J P \& Nida, E A (eds) 1988b. Greek-English lexicon of the New Testament based on semantic domains, vol 2. Cape Town: Bible Society of South Africa.

Malina, B J 1993. The New Testament world: Insights from cultural anthropology, rev ed. Louisville, KY: Westminster.

Malone, M T 2001. Women \& Christianity, vol I: The first thousand years. New York: Orbis.

Marguerat, D 2002. The first Christian historian: Writing the Acts of the Apostles Cambridge: Cambridge University Press. (Society for New Testament studies: Monograph series.)

Martin, C J 1994. The Acts of the Apostles, in Schüssler Fiorenza, E, Searching the scriptures, Vol 2: A feminist commentary. New York: SCM.

Matson, D L 1996. Household conversion narratives in Acts: Pattern and interpretation. Sheffield: Sheffield Academic Press. (Journal for the study of the New Testament: Supplement Series 123.)

Moulton, W F \& Geden, A S (eds) 1963. A concordance to the Greek Testament according to the texts of Westcott and Hort, Tischendorf and the English Revisers. $4^{\text {th }}$ Ed. Edinburgh: T\&T Clarck.

Nestle, E \& E \& Aland, K \& B 1979. Novum Testamentum Graece. 26.Ausgabe. Stuttgart: Deutsche Bibelstiftung.

Oakman, D E 1996. The ancient economy, in Rohrbaugh, R L, The social sciences and New Testament interpretation. Massachusetts, MA: Hendrickson.

Reardon, B 1989. Chaereas and Callirhoe, in Reardon, B, Collected ancient Greek novels. Los Angeles, CA: University of California.

Reimer, I R 1995. Women in the Acts of the Apostles: A feminist liberation perspective. Minneapolis, MN: Fortress.

Robertson, A T 1930. The Acts of the Apostles. Nashville, TN: Broadman. (Word pictures in the New Testament, Volume III.)

Stagg, E \& Stagg, F 1978. Women in the world of Jesus. Edinburgh: Saint Andrew.

Tucker, R A \& Liefeld, W L 1987. Daughters of the church: Women and ministry from New Testament times to the present. Grand Rapids, MI: Zondervan.

Wainwright, E M 1991. Towards a feminist critical reading of the Gospel according to Matthew. Berlin: Walter de Gruyter.

Whitaker, R (ed) 1997. The abridged Brown-Driver-Briggs Hebrew-English lexicon of the Old Testament. Oak Harbor: Logos Research Systems.

Wire, A C 1990. The Corinthian women prophets: A reconstruction through Paul's rhetoric. Minneapolis, MN: Fortress.

Williams, C S C 1964. A commentary on the Acts of the Apostles. London: Adam \& Charles Black. (Black's New Testament Commentaries.)

Witherington III, B 1988. Women in the earliest churches. Cambridge: Cambridge University Press.

Witherington III, B 1998. The Acts of the Apostles: A socio-rhetorical commentary. Grand Rapids, MI: Eerdmans. 